It is quite probable that well records in western New York will supply additional interglacial records as has been so abundantly done by the well records of Minnesota, Iowa and Ohio. The records in New York state referred to above, while few in number, are still of a character to supply indubitable proof of a Prewisconsin ice invasion in this territory.

During the work of compiling literature relating to the life of postglacial and interglacial deposits, it was observed that little or no attention had been given by New York geologists to the fresh-water life of the ancient lakes of the Champlain substage. The gravels of the Niagara River ${ }^{4}$ and certain deposits at Ithaca $^{5}$ appear to be the only localities from which life has been definitely reported. Many years ago $\mathrm{Hall}^{6}$ reported Unios and wood from the ridge bordering the south side of Lake Ontario, which marks the shore of the glacial Lake Iroquois. A careful study of this old beach and especially of bays or lagoons behind the beach proper will surely produce results similar to those obtained by Professor Coleman at Toronto. ${ }^{7}$

Frank Collins Baker

Chicago Academy of Sciences

THE PRODUCTION IN KITTENS INOCULATED WITH ENTAMCEBA TETRAGENA OF PATHOLOGICAL FORMS IDENTICAL WITH ENTAMCEBA HISTOLYTICA

To the Editor of SoIence: Schaudinn stated that the reproduction of $E$. histolytica by sporulation "occurs after a period of lively increase when the conditions of life have deteriorated. In dysentery this is simultaneous with the commencement of healing."

I have been able recently by the rectal inoculation of a succession of kittens with trophozoites of $E$. tetragena to observe during a "period of lively increase" the adolescent trophozoite gradually become reduced in size and to note the production of chromidia in

- Letson, Bull. Buf. Soc., N. S., VII., pp. 238252, 1901.

Tarr, Journ. of Geol., XII., p. 79.

" "Geology of New York," Part IV.

'Bull. Geol. Soc. Amer., XIV., pp. 347-368. large amount in every individual. This appeared first in the third remove as fine particles in the cytoplasm. In the fourth remove, collections of large particles were seen. The nucleus took on the characters of $E$. tetragena, $i$. e., prominent karyosome, and at the time of death of the last set of kittens in the fourth remove, typical tetragena cysts were seen, but associated with them were forms in which bizarre appearances identical with those figured by Hartmann from Schaudinn's histolytica preparations were seen. These are certainly manifestations of pathological cell changes, and represent dislocations of the nucleus, karyorrhexis, karyolysis and extrusion of the nucleus. Many so-called buds were seen, a number of which had become detached from the parent body after the extrusion of chromidia. This budding process seems to be analogous to certain pathological changes in the cytoplasm of mononuclear metazoan cells, for example, in lymphocytes and plasma cells.

The production of budding and other pathological forms identical with the descriptions and drawings of $E$. histolytica, but produced in kittens in a senile precysting race of $E$. tetragena associated with typical tetragena cysts indicates almost certainly that $E$. histolytica is a spurious species, having been described by Schaudinn and Craig from senile races of $E$. tetragena.

Ancon Hospital

\section{S. T. DarLing}

\section{INDOOR HUMIDITY}

To the Editor of Science: In view of the present-day discussion of the subject of indoor humidity some experiments recently carried out by the writer may be of interest to those who, like himself, have been bothered by the bugbear of the "70 per cent." which seems to be the optimum value according to most authorities.

Inside the casing of the hot-air furnace, and right on the dome or hottest part of the firebox, was placed a cast-iron pan with bottom shaped to fit closely. By a simple automatic device connected with the plumbing this was kept full of water, which was found 
to boil vigorously in all but the mildest winter weather. When this was supplemented by a crescent-shaped pan on the "radiator" (also inside the casing) the evaporation reached twenty-five or more gallons a daythis in a house of perhaps 20,000 cubic feet capacity.

A number of observations of the relative humidity were made with a sling psychrometer in both mild and severe weather. The effect of this considerable evaporation was to raise the humidity perhaps 15 per cent. above the 25 per cent. or 30 per cent. which is its winter value in most houses in this climate. When the value exceeded 40 per cent., however, very annoying condensation effects were noticeable; even the double windows were drenched with water, while, with zero weather outside, the baseboards and furniture of bedrooms which had been cold during the night were wet. At 50 per cent. the condensation became unbearable, even the walls-although built with double air space-being wet. With the humidity at 40 per cent., however-and it seldom exceeded this value with the above mentioned evaporation-no bad effects were noticeable, while it has certainly added very materially to the comfort of indoor living and possibly contributed in securing immunity from colds.

In conclusion it seems to the writer that considerable effort is required to raise the humidity even a few per cent., but that this effort is nevertheless well worth while; also that 40 per cent. is as high a humidity as can be obtained in this climate in winter without annoying condensation effects, even in a house with double walls and double windows, while 70 per cent. would mean the atmosphere of a steam laundry.

L. R. INGERSOLL

Madison, WIs.

\section{SCIENTIFIC BOOKS}

Le problème physiologique du Sommeil. By Henri Pí́ron. Paris, Masson et Cie. 1913. Pp. $x v+520$; six figures in text.

This volume makes a notable contribution to the large literature bearing upon the nature and cause of sleep. That the subject is treated in a comprehensive manner is indicated by the headings of the six parts into which the book is divided, namely, the biology of sleep, under which is included a discussion of related conditions in plants and animals; the physiological phenomena characteristic of sleep, the treatment here being limited to the characteristic sleep in man and the mammalia; states analogous to sleep, including such conditions as coma, narcosis, the action of hypnotics, hypnotic and electrical sleep and hibernation; experimental observations upon the factors of sleep; theories of sleep, and lastly a summary of the present state of the problem together with an outline of his own views upon the subject. The bibliographical and critical part of the book seems to be complete and well done. The author quotes a very extensive literature, and, so far as the reviewer can determine from his own knowledge of the subject, the material referred to has been treated with great fairness to the authors concerned. In fact the impartiality and completeness shown in the presentation of the numerous facts and theories ought to make the book an especially valuable source of information for all who are interested in the subject.

Outside this feature.interest attaches chiefly to the experimental contributions made by the author and to the theory which he is led to adopt. His own work, done in collaboration with Legendre, consisted mainly of a study of the toxines produced in dogs kept from sleep during periods varying from 30 to 500 hours. In these animals he obtained evidence of the production of a hypnotoxine which he was able to detect in the blood, brain and cerebrospinal liquid. Incomplete efforts made to isolate this body indicated that it is not dialysable, that it is destroyed by heating to $65^{\circ} \mathrm{C}$. and that it is precipitable by alcohol and can be redissolved in water. In the animals subjected to insomnia histological examination demonstrated that there was a distinct degenerative change in the cortex of the prefrontal region. The cells were diminished in 